\title{
KAJIAN PENGEMBANGAN HOME INDUSTRI LANTING DI DESA KARANG BINANGUN KECAMATAN BELITANG MADANG RAYA KABUPATEN OKU TIMUR
}

\author{
(Pudiyaka)
}

\begin{abstract}
The purpose of this research is to: (1) To know the value added of lanting home industry in Karang Binangun Village Belitang District Madang Raya Regency OKU Timur, (2) To know the profit level of lanting home industry in Karang Binangun Village Belitang District Madang Raya OKU Regency East, (3) To know the amount of contribution given from home industry lanting to household income in Karang Binangun Village Belitang District Madang Raya Regency OKU East Regency OKU East. This research was conducted in Karang Binangun Village Belitang Madang Raya District, OKU Timur Regency. Determining the location intentionally (purposive sampling) with the consideration that in the Village Karang Binangun Belitang District Madang Raya OKU Timur Regency is one of the villages that seek home industry lanting. This research was conducted in July 2014. This research found that home industry lanting give added value for respondents in Karang Binangun Village Belitang Madang Raya District, OKU Timur Regency, that is $R p$ 5,777,92 / Kg. The average income from home industry lanting in Karang Binangun Village is $R p$. $261,614.11$ / production process, $R / C$ ratio of 1.81 , and $B / C$ ratio is 0.81 and Contribution value of business making of lanting to family income is $66,98 \%$.
\end{abstract}

Key Words : Home Industry, Food Processing, Value-added, and Income.

\section{PENDAHULUAN}

\section{A. Latar Belakang}

Ketahanan pangan adalah suatu kondisi terpenuhinya kebutuhan pangan baik dari segi jumlah, mutu, aman, merata dan terjangkau oleh seluruh lapisan masyarakat. Salah satu upaya untuk meningkatkan ketahanan pangan adalah melalui penganekaragaman pangan, yaitu suatu proses pengembangan produk pangan yang tidak bergantung kepada satu jenis bahan saja, tetapi memanfaatkan beraneka ragam bahan pangan. Pengembangan tersebut mencakup aspek produksi, pengolahan, distribusi hingga konsumsi pangan di tingkat rumah tangga (Heni dkk, 2006).

Ubikayu merupakan komoditas tanaman $\mathrm{p}$ angan yang penting sebagai penghasil sumber bahan pangan yang mengandung karbohidrat, bahan baku industri makanan, kimia dan pakan ternak.Beberapa keunggulan lain dari ubikayu ini adalah :

1. Tanaman ini sudah dikenal dan dibudidayakan secara luas oleh masyarakatsebagai bahan ma kananpokok dan sebagai bahan cadangan pa ngan pada musim paceklik.

2. Masyarakat telah terbiasa mengolah ubi kayu dan mengonsumsinya dalam bentuk gatot dan tiwul.

3. Nilai kandungan gizinya cukup tinggi dan

4. Mudah beradaptasi dengan lingkungan atau lah an yang marginal dan beriklim kering.
Di Indonesia ubi kayu dijadikan makanan pokok nomor tiga setelah padi dan jagung. Penyebaran ubi kayu meluas kesemua provinsi di Indonesia. Daerah sentral produksi ubi kayu yang masuk lima besar di Indonesia adalah provinsi Jawa Timur, Jawa Tengah, Jawa Barat, Lampung dan NTT. Pada masa yang akan datang daerah areal penanaman ubi kayu akan diperluas ke luar pulau jawa karena sumber daya lahan yang belum dimanfaatkan secara optimal masih tersedia cukup luas (Anonim, 2008).

Ubi kayu segar memiliki nilai ekonomi yang sangat rendah pada saat panen raya, karena itu perlu suatu upaya meningkatkan nilai tambah (added value) dari ubi kayu dengan mengolah menjadi bernekaragam produk. Potensi nilai ekonomi dan sosial ubi kayu merupakan bahan pangan masa depan yang sangat berguna sebagai bahan baku berbagai industri dan sebagai bahan pakan ternak dan ikan. Ubi kayu pada umumnya digunakan sebagai bahan makanan pokok (Suprapti, 2005).

Sesuai perkembangan teknologi, ubi kayu tidak hanya untuk bahan makanan pokok, tetapi ubi kayu juga dapat diolah menjadi berbagai jenis makanan antara lain, ubi rebus, ubi bakar, ubi goreng, kolak, kerupuk, keripik, tape dan masih banyak jenis yang lainya. Disamping itu ubi juga dapat diolah menjadi tiwul dan tepung tapioka (Wargiono, 2009). 
Tabel 1. Komposisi Gizi Ubi Kayu (100 gram)

\begin{tabular}{lll}
\hline No & Komposisi & Jumlah \\
\hline 1. & Kalori & $146.000 \mathrm{kal}$ \\
2. & Protein & $1,20 \mathrm{gr}$ \\
3. & Lemak & $0,30 \mathrm{gr}$ \\
4. & Karbohidrat & $34,70 \mathrm{gr}$ \\
5. & Kalsium & $33,00 \mathrm{gr}$ \\
6. & Posfor & $40,00 \mathrm{gr}$ \\
7. & Besi & $0,70 \mathrm{gr}$ \\
8. & Vit. A & $0,00 \mathrm{SI}$ \\
9. & Vit. B1 & $0,06 \mathrm{mg}$ \\
10. & Vit. C & $30,00 \mathrm{mg}$ \\
11. & Air & $62,50 \mathrm{gr}$ \\
\hline
\end{tabular}

Sumber: Direktorat Gizi, 2009.

Banyak jenis makanan olahan hasil ubi kayu yang disenangi oleh masyarakat luas. Jenis makanan olahan yang dibuat secara tradisional (kecil-kecilan) termasuk diantaranya adalah lanting. Usaha pembuatan makanan olahan secara tradisional tentu akan berkembang sesuai dengan perkembangan ilmu pengetahuan dan teknologi (Gilarso, 2009).

Lanting (kadang disebut klanting), merupakan makanan ringan sejenis kerupuk yang terbuat dari ubi kayu berbentuk angka delapan atau lingkaran. Lanting dibuat dengan bahan baku ubi kayu, dicampur dengan berbagai bumbu dan dimasak dengan cara digoreng. Lanting berbentuk lingkaran dan pembuatannya memang dibentuk dengan menggunakan jari para pekerja industri tersebut, sampai sekarang pembuatan lanting masih dilakukan secara manual. Asal mulanya lanting hanya mempunyai rasa yang gurih dan asin tetapi sekarang mulai muncul aneka rasa seperti asin pedas dan rasa keju.

Keberadaan lanting ubi kayu bukan merupakan hal baru bagi masyarakat Indonesia. Hal tersebut berkaitan dengan melimpahnya ketersediaan ubi kayu di berbagai daerah di Indonesia. Pengembangan produk ini dinilai masih sangat potensial mengingat besarnya peluang pasar yang dituju dan munculnya beragam diversifikasi produk makanan hasil olahan ubi kayu. Diversifikasi ubi kayu diwujudkan dalam bentuk beranekaragam dan menampakan produk secara keseluruhan sehingga akan lebih disukai konsumen (Hambali, 2007).

Di Desa Karang binangun Kecamatan Belitang Madang Raya Kabupaten OKU Timur merupakan salah satu desa yang mengolah ubi kayu menjadi lanting. Pengolahan lanting sangatlah sederhana akan tetapi mampu meningkatkan pendapatan para petani dalam pemenuhan kebutuhan hidup.

\section{B. Rumusan Masalah}

1. Berapa besar nilai tambah yang diperoleh dari home industri lanting di Desa Karang Binangun Kecamatan Belitang Madang Raya Kabupaten OKU Timur.

2. Apakah home industri lanting di Desa Karang Binangun Kecamatan Belitang Madang Raya Kabupaten OKU Timur menguntungkan.

3. Berapa kontribusi yang diberikan dari home industri lanting terhadap pendapatan rumah tangga di Desa Karang Binangun Kecamatan Belitang Madang Raya Kabupaten OKU Timur.

\section{Tujuan dan Kegunaan}

1. Untuk mengetahui besarnya nilai tambah home industri lanting di Desa Karang Binangun Kecamatan Belitang Madang Raya Kabupaten OKU Timur.

2. Untuk mengetahui tingkat keuntungan home industri lanting di Desa Karang Binangun Kecamatan Belitang Madang Raya Kabupaten OKU Timur.

3. Untuk mengetahui besarnya kontribusi yang diberikan dari home industri lanting terhadap pendapatan rumah tangga di Desa Karang Binangun Kecamatan Belitang Madang Raya Kabupaten OKU Timur Kabupaten OKU Timur.

\section{Model Pendekatan}

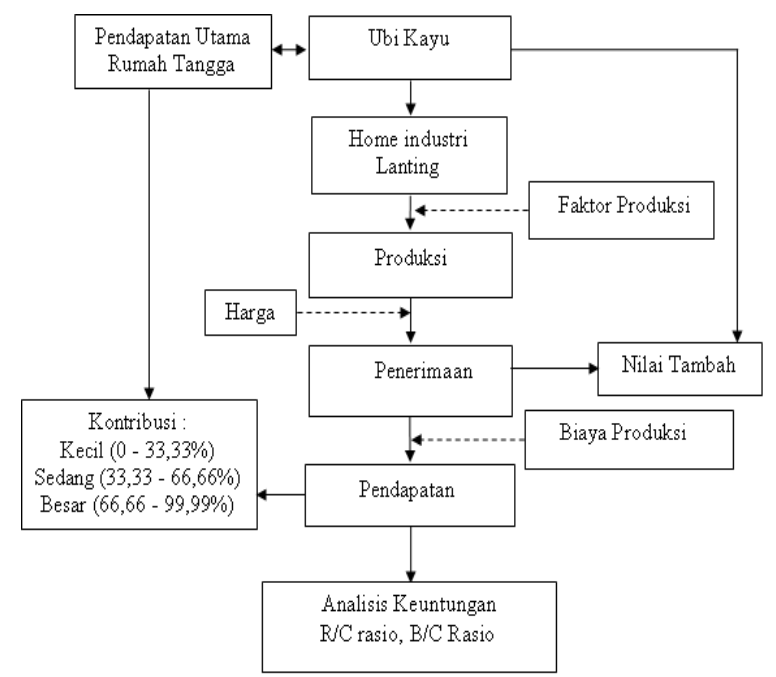

Keterangan :

$\longrightarrow$ Hubungan struktural

Gambar 1. Model pendekatan penelitian secara diagramatik. 


\section{METODOLOGI PENELITIAN}

\section{A. Tempat dan Waktu}

Penelitian ini telah dilaksanakan di Desa Karang Binangun Kecamatan Belitang Madang Raya Kabupaten OKU Timur. Penentuan lokasi secara sengaja (Purposif Sampling) dengan pertimbangan bahwa di Desa Karang Binangun Kecamatan Belitang Madang Raya Kabupaten OKU Timur merupakan salah satu desa yang mengusahakan home industri lanting. Penelitian ini dilaksanakan pada Bulan Juli 2014.

\section{B. Metode Penelitian}

Metode yang digunakan adalah metode sensus. Metode sensus adalah suatu cara pendekatan dengan mewawancarai semua populasi yang ada yaitu semua rumah tangga yang melakukan industri lanting di Desa Karang Binangun. Metode sensus ini bertujuan untuk mengumpulkan informasi secara detil dan lengkap tentang home industri lanting yang dilakukan oleh semua populasi peembuat lanting di Desa Karang Binangun. Untuk memperoleh keterangan dapat digunakan quisioner, wawancara, dan observasi lansung ke daerah penelitian (Nasution, 2004).

\section{Metode Penarikan Contoh}

Metode penarikan contoh yang digunakan pada saat penelitian adalah Metode secara sengaja (Purposive Sampling) yaitu mengambil contoh seluruh populasi berjumlah 18 sampel.

\section{Metode Pengolahan Data}

Pengolahan data dilaksanakan dengan menganalisis data yang ada menggunakan analisis deskriptif kuantitatif. Analisis deskriptif kuantitatif yaitu suatu metode penelitian yang menggunakan angka yang kemudian diolah dianalisis dan ditarik kesimpulan yang menggambarkan objek yang diteliti. Untuk menjawab hipotesis dgunakan rumus matematis sebagai berikut :

a.Untuk menjawab rumusan masalah pertama yaitu menghitung nilai tambah digunakan rumus :

$\mathrm{A}=\mathrm{a}-\mathrm{b}$ (Mubyarto, 2002)

Keterangan :

$\mathrm{A}=$ Nilai tambah lanting $(\mathrm{Rp} / \mathrm{kg})$

$\mathrm{a}=$ Nilai Output (Harga output $\mathrm{x}$ Faktor konversi)

$\mathrm{b}=$ Harga bahan baku

b. Untuk menjawab rumusan masalah kedua yaitu analisis keuntungan menggunakan beberapa rumus berikut :
1) Untuk menghitung biaya produksi digunakan rumus :

$\mathrm{TC}=\mathrm{FC}+\mathrm{VC}$.............(Soekartawi, 2002)

Dimana :

$\mathrm{TC}=$ Total Cost (Biaya total dalam rupiah)

$\mathrm{FC}=$ Fixed Cost (Biaya Tetap dalam rupiah)

$\mathrm{VC}=$ Vriable Cost (Biaya Variable dalam rupiah)

2) Untuk menghitung penerimaan digunakan rumus :

$\mathrm{TR}=\mathrm{P} \times \mathrm{Q}$ (Soekartawi, 2002)

Keterangan :

$\mathrm{TR}=$ Total Revenue $/$ Penerimaan $(\mathrm{Rp})$

$\mathrm{P}=$ Price / Harga komoditas $(\mathrm{Rp})$

$\mathrm{Q}=$ Quantum (jumlah produksi)

3) Untuk menghitung pendapatan digunakan rumus :

$\mathrm{I}=\mathrm{TR}-\mathrm{TC}$ .(Soekartawi, 2002)

Keterangan :

$\mathrm{I}=$ Income $/$ Pendapatan $(\mathrm{Rp})$

$\mathrm{TR}=$ Total Revenue $/$ Penerimaan $(\mathrm{Rp})$

$\mathrm{TC}=$ Total Cost $/$ Biaya Total $(\mathrm{Rp})$

4) Untuk menghitung keuntungan usaha lanting digunakan rumus :

$\mathrm{R} / \mathrm{C}$ Rasio $=\frac{\text { Penerimaan }}{\text { Biaya produksi }}$ (Soekartawi, 2002)

Kriteria :

$\mathrm{R} / \mathrm{C}$ Rasio > 1 maka usaha lanting dinyatakan menguntungkan

$\mathrm{R} / \mathrm{C}$ Rasio = 1 maka usaha lanting dinyatakan impas

$\mathrm{R} / \mathrm{C}$ Rasio < 1 maka usaha lanting dinyatakan tidak

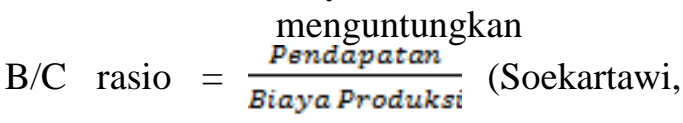

2002)

Kriteria :

B/C Rasio > 0 maka usaha lanting dinyatakan menguntungkan

$\mathrm{B} / \mathrm{C}$ Rasio $=0$ maka usaha lanting dinyatakan impas

$\mathrm{B} / \mathrm{C}$ Rasio < 0 maka usaha lanting dinyatakan tidak menguntungkan

c.Untuk menjawab rumusan masalah ketiga yaitu menghitung kontribusi home industri lanting terhadap pendapatan rumah tangga adalah :

Kontribusi $=\frac{\text { PUP }}{\text { PUP + PUL }} \times 100$ (Nasution dan

Barizi, 2006) 
Keterangan :

PUP $=$ Pendapatan Usaha Lanting $(\mathrm{Rp} / \mathrm{B} \ln )$

$\mathrm{PUL}=$ Pendapatan Usahatani Sawah $(\mathrm{Rp} / \mathrm{Bln})$

Kriteria kontribusi :

a. Kecil apabila memiliki nilai yang berkisar antara $=0-33,33 \%$

b. Sedang apabila memiliki nilai yang berkisar antara $=33,33 \%-66,66 \%$

c. Besar apabila memiliki nilai yang berkisar antara $=66,66-99,99 \%$

\section{HASIL DAN PEMBAHASAN}

\section{Analisis Home Industri Lanting}

Lanting merupakan makanan ringan atau camilan yang berasal dari olahan ubi kayu, dengan kata lain bahan baku dari lanting adalah ubi kayu. Para pelaku home industry lanting di Desa Karang Binangun Kecamatan Belitang Madang Raya Kabupaten OKU Timur memperoleh ubi kayu dari luar desa ataupun di dalam desa itu sendiri. Terkadang juga responden menanam ubi kayu sendiri dan hasilnya diolah menjadi lanting, namun untuk keberlangsungan proses produksi lanting tersebut responden sering mencari bhan baku berupa ubi kayu ke luar desa seperti ke Desa Sari Guna, Desa Sugih Waras, dan desa lain yang sebagian penduduknya menamam ubi kayu. Harga ubi kayu yang dibeli responden relatif murah yaitu $\mathrm{Rp} 1.000$ sampai $\mathrm{Rp} 1500$ sesuai kesapakatan antara penjual dengan responden.

Proses pembuatan lanting yang dilakukan oleh responden di Desa Karang Binangun Kecamatan Belitang Madang Raya Kabupaten OKU Timur dimulai dari penyediaan bahan baku berupa ubi kayu, kemudian ubi kayu tersebut dikupas dan dibersihkan dari kulinya. Setelah dikupas, ubi kayu tersebut dicuci sampai bersih sampai putih bersih. Kemudian ubi kayu yang sudah dicuci bersih dikukus hingga masak atau lunak sekitar 30 menit sampai satu jam atau sampai benar-benar lunak agar mempermudah dalam proses selanjutnya.

Proses selanjutnya yaitu pelumatan atau penumbukan, ubi kayu yang sudah dikukus lunak tadi dihaluskan dan dipisahkan dari kayu bagian tengah (sontrot) nya, dalam proses pelumatan tersebut adonan ubi kayu dicampur dengan bubumbu halus yang terdiri dari bawang putih, garam, dan roiko. Setelah adonan dan bumbu halus tercantur merata, barulah adonan tersebut di cetak dengan mesin berbentuk silinder-silinter atau pipa kecil kemudian dipotong dan dibentuk berbertuk lingkaran secara manual menggunakan tangan. Setelah dibentuk, bentukan tersebut dijemur di bawah sinar matahari antara 3-4 jam atau tergantung cuaca, sampai kering. Kemudian lanting yang sudah dijemur tersebut digoreng di dalam minyak panas dengan api sedang sampai lanting berwarna kuning kecoklatan. Penggunaan api sedang bertujuan agar lanting yang digoreng matang merata dan tidak gosong.

Proses terakhir yaitu pengemasan, pengemasan dilakukan saat lanting sudah dingin. Jika lanting dikemas dalam keadaaan panas atau hangat, lanting cepat layu atau tidak renyah lagi. Lanting dikemas dalam plastik besar, dalam satu plastik berisi antara 10 sampai $15 \mathrm{~kg}$ lanting. Lanting yang sudah dikemas siap dijual oleh responden ke pedagang pengumpul atau pedadang eceran yang membeli lanting tersebut langsung dateng ke tempat produksi. Harga jual lanting yaitu antara $\mathrm{Rp} 12.000 / \mathrm{Kg}$ sampai $\mathrm{Rp} 13.000 / \mathrm{Kg}$.

Dalam suatu usaha ataupun home indutri, perlu dilakukan analisis keuntungannya. Berikut ini uraian analisis keuntungan home industri lanting di Desa Karang Binangun Kecamatan Belitang Madang Raya Kabupaten OKU Timur. Data yang diperoleh berdasarkan survei dan wawancara langsung dengan responden di lapangan, diolah dengan menggunakan analisis matematis. Analisis matematis dilakukan dengan cara data yang sudah dikumpulkan diolah berdasarkan rumus-rumus yang sesuai dengan rumusan masalah. Pengolahan data secara matematis dikerjakan dengan bantuan komputer software Microsoft Excel. Berikut ini akan dijelaskan secara terperinci hasil analisis data tersebut.

1. Biaya Produksi

Biaya produksi adalah biaya yang digunakan oleh produsen untuk menjalankan proses produksinya sehingga menghasilkan suatu produk. Sedangkan menurut Kartasapoetra (2001) biaya produksi merupakan semua pengeluaran yang harus di keluarkan oleh produsen untuk memperoleh faktor-faktor produksi dan bahanbahan penunjang lainnya yang akan digunakan agar produk tertentu yang telah direncanakan dapat terwujud dengan baik.

Biaya produksi dalam penelitian ini adalah semua biaya yang dikeluarkan oleh responden yang melakukan home industri lanting untuk memproduksi lanting sampai siap dipasarkan. Rata-rata biaya produksi yang dikeluarkan oleh responden dalam home industri pembuatan lanting di Desa Karang Binangun Kecamatan Belitang Madang Raya Kabupaten OKU Timur adalah sebesar Rp 319.483,11/proses produksi. Total 
biaya tersebut terdiri dari biaya variabel sebesar Rp 289.036,67/ proses dan biaya tetap sebesar Rp $30.446,45 /$ proses. Biaya tetap dalam usaha ini terdiri dari biaya penyusutan alat dan biaya sewa tempat.

Tempat yang digunakan oleh responden dalam usaha pembuatan lanting ini adalah di rumah masing-masing responden. Namun, dalam perhitungannya biaya sewa tempat harus tetap dipehitungkan. Rata-rata biaya sewa tempat home industri lanting yaitu sebesar Rp 26.485,06/proses produksi. Komponen biaya tetap yang lain yaitu penyusutan alat sebesar Rp 3.961,39/proses produksi. Alat-alat yang digunakan dalam usaha pembuatan lanting tersebut terdiri dari pisau, bak, tungku, dandang, mesin giling, wajan, sotel, serok, tempat jemur, tampah, dan timbangan.

Biaya variabel yang dikeluarkan responden terdiri dari biaya pengadaan sarana produksi variabel rata-rata sebesar $\mathrm{Rp} 200.564,44 /$ proses produksi dan upah tenaga kerja rata-rata sebesar Rp 88.472,22/proses produksi (Lampiran 5). Sarana produksi variabel terdiri dari pembelian ubi kayu, garam, roiko, bawang putih, minyak goreng, pewarna makanan, plastik, rafia, kayu bakar, dan bensin. Tenaga kerja yang digunakan dalam usaha pembuatan lanting ini terdiri dari tenaga kerja keluarga masing-masing. Dalam analisis suatu usaha, upah tenaga kerja keluarga pun tetap harus diperhitungkan untuk mengetahui untung dan rugi dari usaha yang dilakukan. Berikut ini rincian biaya produksi pembuatan lanting yang dikeluarkan responden di Desa Karang Binangun dalam satu kali proses produksi :

Tabel 2.Biaya Produksi Usaha Pembuatan Lanting di Desa Karang Binangun.

\begin{tabular}{llc}
\hline No & Uraian & Jumlah (Rp Proses) \\
\hline 1 & Biaya Tetap & $30.446,45$ \\
& a. Sevva Tempat & $26.485,06$ \\
& b. Peyusutan Alat & $3.961,39$ \\
2 & Biaya Variabel & $289,036,67$ \\
& a. Sarann Produksi & $200.564,44$ \\
& b. Upah Tenagga Kerja & $88.472,22$ \\
3 & Total Biaya Produksi & $319.483,11$ \\
\hline
\end{tabular}

Sumber: Olahan Data Primer, 2014.

2. Produk, Harga Jual, Penerimaan, Pendapatan Produksi adalah suatu proses pendayagunaan segala sumber yang tersedia untuk mewujudkan hasil yang terjamin kualitas dan kuantitasnya, terkelola dengan baik sehingga merupakan komoditi yang diperdagangkan
(Kartasapoetra, 2003). Suatu proses produksi bertujuan untuk menghasilkan produk atau barang. Produk yang dihasilkan dari home industri ini adalah lanting yang sudah digoreng dan siap dikonsumsi oleh konsumennya.

Lanting yang dihasilkan oleh responden di Desa Karang Binangun ini hanya satu jenis, yaitu lanting berbentuk bulat, dan satu rasa yaitu rasa original (gurih). Hanya saja ada beberapa responden (dua responden) yang memproduksi lanting dua warna yaitu warna merah dan warna putih agar lantingnya lebih bervariasi, namun rasanya tetap sama original. Berbeda dengan lanting yang diproduksi di daerah asalnya yaitu Kebumen, produsen lanting di Kebumen sudah inovatif, mereka membentuk lantingnya seperti angka delapan dan membuat lantingnya menjadi beraneka rasa, sehingga konsumen lebih tertarik dan tidak mudah bosan untuk mengonsumsinya.

Home industri lanting di Desa Karang Binangun rata-rata dalam satu kali proses produksi, mampu menghasilkan produk lanting sebesar 45,69 $\mathrm{kg}$ lanting setiap kali proses produksi dengan harga jual rata-rata adalah $\mathrm{Rp}$ 12.722,22 (Lampiran 11). Harga yang digunakan masing-masing responden dalam menjual lanting berbeda-beda namun perbedaannya tidak signifikan yaitu antara Rp 13.000, Rp 12.000, atau Rp 12.500, perbedaan harga tersebut disesuaikan dengan harga yang disepakati antara masingmasing responden dengan konsumen atau pembelinya.

Sebagian besar responden home industri lanting di Desa Karang Binangun menjual lantingnya hanya ke pedagang pengumpul yang datang langsung ke tempat produksinya untuk membeli lanting hasil produksinya. Kebanyakan pedagang pengumpul tersebut sudah lama berlangganan membeli lanting pada responden. Pedagang pengumpul tersebut kemudian menjual kembali lanting tersebut ke pasar ataupun ke pengecer. Sehingga hal tersebut lah yang menyebabkan harga jual lanting dari responden $(\mathrm{Rp} 12.000$ - Rp 13.000/kg) relatif lebih rendah rendah dibanding harga di pasar yaitu antara $\mathrm{Rp}$ 15.000 - Rp 16.000/kg lanting.

Berdasarkan hasil perhitungan, rata-rata penerimaan yang diperoleh responden adalah sebesar $\mathrm{Rp}$ 581.097,22/proses produksi. Penerimaan adalah hasil kali jumlah produk dengan harga jual yang berlaku. Penerimaan merupakan hasil penjualan keseluruhan yang belum dikurangi oleh biaya produksi. Hasil pengurangan dari penerimaan dikurang biaya produksi disebut pendapatan. Rata-rata 
pendapatan yang diperoleh oleh responden dari home industri lanting di Desa Karang Binangun ini adalah sebesar Rp 261.614,11/proses produksi. Hal tersebut berarti, responden mendapatkan keuntungan sebesar pendapatan tersebut. Rincian jumlah produk, harga, penerimaan, dan pendapatan disajikan dalam tabel berikut :

Tabel 3. Penerimaan dan Pendapatan

\begin{tabular}{llc}
\hline No & Uraian & Jumlah \\
\hline 1 & Produksi (KgProses) & 45,69 \\
2 & Harga Jual (Rp/Kg) & $12.722,22$ \\
3 & Penerimaan (Rp/Proses) & $581.097,22$ \\
4 & Biaya Produksi (Rp/Proses) & $319.483,11$ \\
5 & Pendapatan(Rp/Proses) & $261.614,11$ \\
\hline
\end{tabular}

Sumber: Olahan Data Primer, 2014.

\section{R/C Rasio, B/C Rasio, dan Nilai Tambah}

Analisis $\mathrm{R} / \mathrm{C}$ rasio adalah analisis yang dilakukan untuk mngetahui untung rugi suatu usaha dengan membandingkan antara total penerimaan dan biaya produksi yang telah dikeluarkan. Kriteria nilai R/C rasio adalah jika lebih besar dari satu maka usaha tersebut untung, jika nilainya sama dengan satu artinya uaha tersebut impas, dan jika nilai $\mathrm{R} / \mathrm{C}$ rasionya lebih kecil dari satu maka usaha tersebut rugi. Suatu usaha dikatakan impas jika jumlah penerimaan yang diperoleh sama dengan jumlah biaya produksi yang dikeluarkan dalam usaha tersebut.

Tabel 12. R/C Rasio, B/C Rasio, Nilai Tambah

\begin{tabular}{lll}
\hline No & Uraian & Jumlah \\
\hline 1 & Biaya Produksi (TC)(Rp/Proses) & $319.483,11$ \\
2 & Penerimaan (TR) (Rp/Proses) & $581.097,22$ \\
3 & Pendapatan (I) (Rp/Proses) & $261.614,11$ \\
4 & R/C Rasio & 1,81 \\
5 & B/C Rasio & 0,81 \\
6 & Nilai Tambah (Rp/Kg) & $5.777,92$ \\
\hline
\end{tabular}

Sumber: Olahan Data Primer, 2014.

Berdasarkan tabel diatas, diperoleh rata-rata nilai $\mathrm{R} / \mathrm{C}$ rasio dalam home industri lanting di Desa Karang Binangun Kecamatan Belitang Madang Raya adalah sebesar 1,81. Hal tersebut dapat diartikan setiap Rp 1.000 yang dikeluarkan dalam home industri tersebut, akan menghasilkan penerimaan $\mathrm{Rp} 1.810$.

Selain nilai $\mathrm{R} / \mathrm{C}$ rasio, analisis keuntungan dapat dilihat juga dengan nilai $\mathrm{B} / \mathrm{C}$ rasio, yaitu hasil bagi antara pendapatan dengan biaya produksi total. Kriteria B/C rasio adalah jika lebih besar dari 0 (nol) maka usaha tersebut untung, jika nilainya sama dengan nol artinya usaha tersebut impas, dan jika nilai $\mathrm{B} / \mathrm{C}$ rasionya lebih kecil dari nol maka usaha tersebut tidak menguntungkan atau rugi.
Rata-rata nilai $\mathrm{B} / \mathrm{C}$ rasio dalam home industri lanting di Desa Karang Binangun adalah sebesar 0,81. Hal tersebut dapat diartikan bahwa setiap Rp 1.000 yang dikeluarkan dalam home industri tersebut, akan menghasilkan pendapatan bersih setelah dikurangi biaya sebesar Rp 810 .

Nilai tambah merupakan nilai yang muncul karena adanya suatu perlakuan dengan tujuan untuk meningkatkan pendapatan atau keuntungan dari suatu benda atau usaha. Nilai tambah menjadi suatu hal yang mutlak untuk dimiliki oleh sebuah usaha. Dalam usaha pembuatan lanting ini, nilai tambah yang dimaksud adalah nilai tambah ubi kayu sebagai bahan baku pembuatan lanting setelah dijadikan makanan olahan berupa lanting. Nilai tambah diperoleh dari selisih nilai output dengan harga bahan baku dalam hal ini adalah harga ubi kayu. Nilai tambah dalam home industri pembuatan lanting ini adalah sebesar Rp $5.777,92 / \mathrm{Kg}$.

\section{Kontribusi}

Kontribusi dalam penelitian ini adalah besarnya nilai sumbangan yang diberikan dari pendapatan usaha pembuatan lanting terhadap pendapatan total keluarga responden di Desa Karang Binangun.

Menurut Hanafie (2010) kontribusi merupakan besarnya sumbangan yang berupa sejumlah barang, jasa, dan finansial yang diberikan dari setiap usaha tertentu yang jumlahnya dapat dikelompokkan beberapa kriteria yakni rendah, sedang, dan besar terhadap pendapatan total keluarga.

Sebagian besar penduduk Desa Karang Binangun bermata pencaharian sebagai petani. Begitu pun dengan responden dalam penelitian ini, semua responden dalam penelitian ini berusahatani padi sawah sebagai usaha lain selain usaha pembuatan lanting. Pendapatan dari usahatani padi sawah, berdasarkan hasil survei dan wawancara langsung kepada responden adalah sebesar Rp 1.833.333,33/bulan.

Berdasarkan hasil perhitungan, didapatkan nilai kontribusi home industri lanting terhadap pendapatan keluarga adalah sebesar 66,98\%. Berarti bahwa pendapatan dari home industri lanting memberikan kontribusi besar terhadap pendapatan keluarga responden di Desa Karang Binangun. Hal ini sesuai dengan pendapat Nasution dan Barizi (2006) bahwa terdapat tiga kriteria kontribusi, yaitu kecil apabila nilainya 0$33,33 \%$, sedang apabila 33,33-66,66 \%, dan besar apabila nilai kontribusinya 66,66-99,99\%. 


\section{IV.KESIMPULAN DAN SARAN}

\section{A. Kesimpulan}

Berdasarnya hasil penelitian dan analisis yang telah dilakukan, maka dapat ditarik kesimpulan sebagai berikut:

1. Home industri lanting memberikan nilai tambah bagi responden di Desa Karang Binangun Kecamatan Belitang Madang Raya Kabupaten OKU Timur, yaitu sebesar Rp $5.777,92 / \mathrm{Kg}$.

2. Rata-rata pendapatan dari home industri lanting di Desa Karang Binangun adalah sebesar Rp. 261.614,11/proses produksi, nilai $\mathrm{R} / \mathrm{C}$ rasio sebesar 1,81 , dan nilai $\mathrm{B} / \mathrm{C}$ rasio adalah sebesar 0,81 .

3. Nilai kontribusi dari usaha pembuatan lanting terhadap pendapatan keluarga adalah sebesar $66,98 \%$.

\section{B.Saran}

Saran yang dapat diajukan bagi responden usaha pembuatan lanting di Desa Karang Binangun adalah :

1. Untuk meningkatkan permintaan pasar/konsumen terhadap lanting perlu dilakukan inovasi rasa agar rasa lanting bervariasi, misalkan rasa balado, rasa jagung bakar, rasa pedas, dan lain sebagainya.

2. Berdasarkan hasil analisis keuntungan, prospek keuntungan yang didapat dari home industri lanting cukup menguntungkan. Oleh karena itu, sebaiknya jumlah produksi lanting di Desa Karang Binagun lebih ditingkatkan, dan pemasaran produk lantingnya pun sebaiknya diperluas agar pendapatan yang diperoleh dapat meningkat.

\section{DAFTAR PUSTAKA}

Anonim. 1995. Standar Nasional Indonesia. Dewan Standarisasi Nasional. Jakarta.

Anonim. 2003. Sensus Pertanian 2003 : Angka Nasional Hasil Pendaftaran Industri Rumah Tangga. Adan Pusat Statistik. Jakarta.

Anonim. 2014. Daerah Penyebaran Tanaman Ubi Kayu. Departemen Pertanian. Jakarta.
Anonim. 2014. Pembuatan Lanting dari Singkong. http://harianresep.blogspot.com /2014/08/resep-lanting.html.

Anonim. 2014. Pengertian Nilai Tambah. http://sofianomicrakyat.blogspot.Com 12014/08/ pengertian-nilai-tambahdalam.html.

Boediono. 2001. Ekonomi Mikro. Balai Penelitian Fakultas Ekonomi. Institut Pertanian Bogor, Bogor.

Gilarso. 2009. Teknologi Pengolahan Pangan Tradisional. CV . Bima Pustaka. Yogyakarta.

Heni, Djaafar dan S. Rahayu. 2006. Diversifikasi Teknologi Pengolahan Jagung untuk Menunjang Agroindustri di Pedesaan. Prosiding Seminar Nasional. Universitas Muhamadiyah Yogyakarta.

Hernanto, F. 2004. Ilmu Usaha Tani. Penebar Swadaya : Jakarta.

Kartasapoetra, A.G. 2003. Manajemen Pertanian. Gramedia Jakarta.

Manulang, M. 2000. Dasar-Dasar Manejemen Pertanian. Ghalia Indonesia : Jakarta.

Moesher, AT. 2003. Menggerakkan dan Membangun Pertanian. Syarat-syarat Pokok Pembangunan dan Modernisasi. Departemen Pertanian : Jakarta.

Mubyarto. 2000. Ekonomi Manajerial. Raja Grafindo. Jakarta.

Mubyarto. 2002. Ekonomi Manejerial. LP3ES : Jakarta.

Nasution, S. 2004. Metode Research. Bumi Aksara. Jakarta.

Nasution, A.H dan Barizi. 2006. Metode Statistika untuk Penarikan Kesimpulan. PT Gramedia. Jakarta.

Pasaribu. 2012. Perencanaan dan Evaluasi Proyek Agribisnis Konsep dan Aplikasi. Yogyakarta.

Rukmana, R. 2005. Ubi Kayu, Budidaya dan Pasca Panen. Kanisus. Yogyakarta. 
Sjarkowi, F. 2010. Manajemen Pembangunan Agribisnis. CV. Baldad Grafiti Press Palembang.

Sjarkowi, S dan M Sufri. 2004. Manajemen Agribisnis. Baldad Grafiti Press. Palembang.

Soekartawi. 2002. Analisis Usaha Tani. Universitas Indonesia. Jakarta.

Soekartawi. 2002. Teori Ekonomi Produksi. Rajawali. Jakarta.

Suratiyah, K. 2003. Ilmu Usaha Tani. Penebar Swadaya : Jakarta.
Umar, H. 2000. Study Kelayakan Bisnis, PT. Raja Grafindo Persada. Jakarta.

Wargiono. 2009. Diversifikasi Tanaman Pangan. Afabeta. Bandung. 